\title{
COMPARING LEVELS OF COMPLIANCE WITH PUBLIC PROCUREMENT ACT, 2007 IN PROJECT DELIVERY BETWEEN FEDERAL AND STATE TERTIARY INSTITUTIONS IN SOUTHWEST, NIGERIA
}

\author{
Ebenezer Olutide Bamidele \\ Building Technology Department, The Federal Polytechnic, Ilaro, Nigeria \\ ebenezer.bamidele@federalpolyilaro.edu.ng.
}

\begin{abstract}
Public Procurement in Nigeria is governed by Public Procurement Act, (PPA) 2007. State Public entities do not consider it obligatory to comply with the Act, being an Act of Federal Parliament with State Governments being autonomous and having their own Parliaments. This study investigates the levels of compliance (LOC) with the Act by Federal and State Tertiary Institutions (PTIs) in Southwest, Nigeria. The objectives are to evaluate and compare the LOC with the Act by the two categories of PTIs. A questionnaire survey approach covering the entire 44 PTIs in Southwest, Nigeria was adopted. Data collected were analysed using mean and t-test. The result reveals that the two categories of institutions did not comply with one provision of the Act while they recorded same levels of compliance in another two provisions, however Federal PTIs complied more than State PTIs in the remaining provisions. The result of test of research hypothesis revealed that the difference in the compliance levels by the two categories differ significantly only in one provision of the Act. It is therefore concluded that Federal PTIs did not perform better and that compliance with the Act by the two categories of PTIs is the same.
\end{abstract}

Keywords: Compliance, Nigeria, project delivery, public procurement act, public tertiary institutions.

Cite this Article: Ebenezer Olutide Bamidele, Comparing Levels of Compliance with Public Procurement Act, 2007 in Project Delivery between Federal and State Tertiary Institutions in Southwest, Nigeria. International Journal of Civil Engineering and Technology, 11(4), 2020, pp. 161-170.

https://iaeme.com/Home/issue/IJCIET?Volume=11\&Issue $=4$

\section{INTRODUCTION}

Procurement constitutes an important activity in every organization in any country of the world. Mukura, Shalle, Kanda and Ngatia (2016) maintained that public procurement is 
considered as a very important factor in economic and business circles globally. As a result of the economic and social implications of public procurement, it is necessary to ensure that transparency, openness and accountability are adhered to in procurement processes in order to ensure successful delivery of all activities that are involved. Claren (2017) maintained that the first International Standard for sustainable procurement (ISO 20400) provided guidelines on development and implementation of sustainable procurement practices and policies by an organization. The standard defined the principles of transparency and accountability that ensures sustainability in procurement. Transparency International (2006) maintained that Nigerian procurement laws lacked separate procurement regulatory and execution functions, institutionalization of public procurement regulatory authorities, establishment of independent review mechanisms required for making public procurement related information easily available to the general public among others. Sequel to the enactment of the Public Procurement Act of 2007, Public Procurement in the country was fraught with corruption of several magnitudes because of the absence of statutory regulations as well as regulatory authority for monitoring procurement procedure in the public sector (Innocent et al., 2015). In an attempt to put in place procurement procedures and practices that would meet international and regional standards and requirements on procurement such as United Nations Commission on International Trade Law (UNCITRAL), the Common Market for Eastern and Southern Africa (COMESA), and the West African Economic and Monetary Union (WAEMU) and to ensure transparency and accountability in public procurement, Nigeria embarked on a reform of its existing procurement laws (Public and Private Development Centre PPDC, 2012).

The reform led to the enactment of the Public Procurement Act of 2007. The Public Procurement Act (PPA) is an Act of the Federal Parliament. It was promulgated to address the problem of corruption and lack of transparency which was prevalent in public procurement in the past, therefore it is meant to be complied with by all Federal Ministries, Extra-ministerial offices, Departments, Agencies, Parastatals, Corporations and all other public entities set up by Nigeria Constitution or Act of the National Assembly. Section 15 subsection 1 on scope of application of the Act provides that the Act shall apply to all procurement of goods, works and services carried out by; (1) the Federal Government and all its procurement entities and (2) all other entities that derive at least $35 \%$ of the funds appropriated or proposed to be appropriated from the Federation Share of Consolidated Revenue Fund (FGN, 2007). The implication of this provision is that the Act applies to all Tiers of Government in Nigeria namely; Federal, State and Local Governments. The scope of application of the Act covers all the Tiers of Government that derive their funds from the Consolidated Revenue Fund. However, the three tiers of Government are known to be autonomous and have separate Parliaments. The current argument is whether or not the provisions of the Act enacted by a Federal Parliament should apply to State Governments who though derive their funds from the Consolidated Revenue Fund, have autonomous Parliament. In view of this argument, this study investigates the levels of compliance with the PPA 2007 by Federal and State owned Public Tertiary Institutions. The objectives are to evaluate and compare the Level of Compliance (LOC) with the Act by the two categories of PTIs. The achievement of the objective will enable stakeholders in the construction industry to know whether or not the goals of the Act are being achieved at the State level of Government.

\section{REVIEW OF LITERATURE}

Good governance is manifested in efficient and effective management of public transactions in a way that ensure a reduction of cost and time through a set of clear and unambiguous procurement framework. Poor governance on the other hand is attributed to lack of existence and implementation of good procurement practices and procedures. This resulted into waste 
and delays and is often the cause of allegations of corruption and government inefficiency (BPP, 2011). Sound management of public funds was discovered to be linked with proper application of procurement procedures, rules and regulations (Hunja, 2003). Past governments in Nigeria before the year 1999 experienced several incidences of fraud, corruption and many unwholesome procurement practices. This was attributed to prolonged military rule and absence of statutory laws on which public procurement were based (Musa et al., 2014; Kareem, Asa \& Lawal 2014). Nigeria, like other countries of the world began the race of public reforms which dated back to 1999 (Musa, Success \& Nwaorgu, 2014). Following the return to civil rule in 1999, the Nigerian government realized the enormous level of corruption in the country and took drastic steps aimed at addressing it in the public service. The government initially submitted an Executive Bill to the National Assembly which led to enactment of the Independent Corrupt Practices and Other Related Offences Commission Act in 2000. Furthermore, government in attempt to address the issue of corruption in public procurement also proposed to enact a Public Procurement Bill to introduce international standard practices and regulations in public procurement. In the attempt to realize this, the federal government invited the World Bank to first conduct a nationwide assessment of public corruption. The result of that assessment carried out in conjunction with a national task force, Country Procurement Assessment Report (CPAR) 2000, formed the basis of the Public Procurement Act, 2007. The CPAR was a detailed diagnosis of the Nigerian procurement system and included both findings and recommendations. The report of the CPAR discovered several deficiencies in the country procurement system. It revealed that Nigeria did not have a public procurement law and there was no institution with the responsibility of issuing policy direction on public procurement in the country. It also discovered the absence of a well spelt standards for carrying out procurement. The absence of institution for issuing policy direction was discovered to be the emergence of irregularities, sharp practices, graft and bad management of public procurement in Nigeria (Sope, 2014).

Following the enactment of the Public Procurement Act, 2007 on the advice of the World Bank, the Federal Government established the National Council on Public Procurement (NCPP) and Bureau of Public Procurement (BPP) as the regulatory body to ensure implementation and compliance with the provisions of the Act. However, several years after the enactment of the Act, studies still discovered the prevalence of corruption and sharp practices which were the hallmarks of pre-PPA period. Jibrin et al. (2014) maintained that the problem with public procurement in Nigeria is not about non-existence of procurement regulations but rather non-compliance and inadequate implementation of the regulations by the various organs of government namely: Ministries, Departments, Agencies, Parastatals and Extra Ministerial Departments. Ayangade et al. (2009) considered the Nigerian construction industry as one with the problem of non-compliance with regulations and processes involved in procurement and this is common especially in the building industry. Ayangade et al. (2009), Wahab (2014) and Hyancinth and Yibis (2017) discovered that compliance with the Act by the various organs of government in Nigeria fall short of expectations after more than a decade of the enactment of the Act. Non-compliance with laid down regulatory framework during procurement process by relevant procuring entities has culminated into arrays of irregular decisions occasioned by poor output in the construction industry producing adverse effect on product procured and the nation in particular (PPDA, 2006).

\section{RESEARCH METHODOLOGY}

The study covers Southwest, which is one of the six geo-political zones in Nigeria. The zone comprises of six states namely; Lagos, Ogun, Oyo, Osun, Ekiti and Ondo States. A field survey involving all the Federal and State owned Public Tertiary Institutions (PTIs) in the zone was conducted. The study population is made up of two subjects namely Public Tertiary 
Institutions (PTIs) and construction projects executed by Federal and State Governments PTIs covered by the survey. The PTIs consist of Universities, Polytechnics and Colleges of Education. The population of the study consists of 44 Federal and State owned Public Tertiary Institutions located in the six (6) states covered by the study area. The website of Joint Admission and Matriculation Board (JAMB 2017), the body responsible for the conduct of examinations and admission into all Tertiary Institutions in Nigeria revealed that the zone had 44 Public Tertiary Institutions consisting of 17 Federal and 27 States PTIs. In view of the population frame, the entire 44 PTIs were selected as the sampling frame and sample size for the study. For this reason, census sampling technique was adopted in selecting the study sample.

In the attempt to compare the levels of compliance with PPA, 2007 by the two categories of Institutions and establish whether or not Federal Tertiary Institutions complied more than their State counterparts, a research hypothesis was formulated. The hypothesis states that there is no significant difference in the levels of compliance with Public Procurement Act 2007 between Federal PTIs and State PTIs. The results of the hypothesis are expected to reveal the significant similarities and differences in compliance with the Procurement Act by Federal and State PTIs.

The research instrument adopted for the survey was a structured questionnaire. 44 questionnaires were administered by two research assistants to the Institutions Procurement Officers who were Builders, Architects, Quantity Surveyors and Civil Engineers. The Procurement Officers who were the head of Procurement Units of the Institutions were responsible for the implementation and compliance with the PPA, 2007 during procurement process. Thirty-nine (39) provisions of the PPA, 2007 relevant to construction project procurement were selected for the study. Respondents were requested to indicate 'Yes' for the provisions of the PPA, 2007 which they complied with when procuring construction projects in their Institutions and 'No' for provisions they did not comply with. All the 44 questionnaires administered to the respondents were returned.

Data collected were processed using Statistical Package for Social Sciences Version 20 software. The levels of compliance with the provisions of the PPA 2007 by each PTI was analysed as the percentage of PTIs that complied with the provision divided by total PTIs. The hypothesis of the study was tested using t test at $p$-value $\leq 0.05$, the rule for the rejection of the hypothesis is that when the calculated $p$-value $\leq 0.05$, the test rejects the hypothesis but when the calculated p-value $>0.05$, the test fails to reject the hypothesis.

\section{RESULTS AND DISCUSSION}

One of the objectives the study is to evaluate the LOC with the Act by the two categories of PTIs in Southwest, Nigeria. In order to achieve the objective of the study, 39 provisions of the Public Procurement Act relevant to procurement of construction projects were selected. Respondents were requested to indicate 'Yes' for the provisions which they complied with and 'No' for the provisions which they did not comply with during procurement of construction projects in their Institutions. Data collected were analyzed to determine the level of compliance with PPA, 2007 using percentage. The results are presented in Table 1. 
Table 1 Result of difference in the levels of compliance with PPA, 2007 between Federal and State owned Tertiary Institutions.

\begin{tabular}{|c|c|c|c|c|c|c|}
\hline Institution's Ownership Category & $\mathbf{N}$ & Mean & t-value & Df & p-value & Diff \\
\hline \multicolumn{7}{|l|}{ Compliance with funding of capital projects } \\
\hline Federal & 17 & 0.50 & 1.110 & 42 & 0.273 & Ns \\
\hline State & 27 & 0.33 & & & & \\
\hline \multicolumn{7}{|l|}{ Compliance with obtaining $\mathrm{CNO}$} \\
\hline Federal & 17 & 0.30 & 0.687 & 42 & 0.496 & Ns \\
\hline State & 27 & 0.21 & & & & \\
\hline \multicolumn{7}{|l|}{ Compliance with basis for award of contract } \\
\hline Federal & 17 & 0.75 & -1.060 & 42 & 0.295 & Ns \\
\hline State & 27 & 0.88 & & & & \\
\hline \multicolumn{7}{|l|}{ Compliance with period for obtaining $\mathrm{CNO}$} \\
\hline Federal & 17 & 0.70 & 1.623 & 42 & 0.112 & Ns \\
\hline State & 27 & 0.46 & & & & \\
\hline \multicolumn{7}{|l|}{$\begin{array}{l}\text { Compliance with procedure for procurement of capital } \\
\text { project }\end{array}$} \\
\hline Federal & 17 & 0.80 & -0.665 & 42 & 0.510 & Ns \\
\hline State & 27 & 0.88 & & & & \\
\hline \multicolumn{7}{|l|}{ Compliance with bidding time frame before award } \\
\hline Federal & 17 & 0.25 & 1.060 & 42 & 0.295 & Ns \\
\hline \multirow{2}{*}{\multicolumn{7}{|c|}{ Compliance with minimum bids before award }} \\
\hline & & & & & & \\
\hline Federal & 17 & 0.75 & 0.592 & 42 & 0.557 & Ns \\
\hline \multirow{2}{*}{\multicolumn{7}{|c|}{ Compliance with procedure of payment }} \\
\hline & & & & & & \\
\hline Federal & 17 & 0.90 & -0.187 & 42 & 0.852 & Ns \\
\hline State & 27 & 0.92 & & & & \\
\hline \multicolumn{7}{|l|}{ Compliance with contractor selection criteria } \\
\hline Federal & 17 & 0.56 & 0.421 & 42 & 0.676 & Ns \\
\hline State & 27 & 0.53 & & & & \\
\hline \multicolumn{7}{|l|}{ Compliance with process of excluding bids from evaluation } \\
\hline \multicolumn{7}{|l|}{ Federal } \\
\hline \multirow[t]{2}{*}{ State } & 17 & 0.30 & 1.888 & 42 & 0.066 & Ns \\
\hline & 27 & 0.08 & & & & \\
\hline \multicolumn{7}{|l|}{ Compliance with bidding/contract documentation language } \\
\hline Federal & 17 & 0.90 & -0.752 & 42 & 0.456 & Ns \\
\hline State & 27 & 0.96 & & & & \\
\hline \multicolumn{7}{|l|}{$\begin{array}{l}\text { Compliance with time to prepare/transmit procurement } \\
\text { proceedings to BPP }\end{array}$} \\
\hline Federal & 17 & 0.25 & 0.000 & 42 & 1.000 & Ns \\
\hline State & 27 & 0.25 & & & & \\
\hline \multicolumn{7}{|l|}{ Compliance with treatment of procurement documents } \\
\hline Federal & 17 & 0.00 & - & - & - & \\
\hline State & 27 & 0.00 & & & & \\
\hline \multicolumn{7}{|l|}{ Compliance with award of contracts of projects } \\
\hline Federal & 17 & 0.45 & -0.594 & 42 & 0.556 & Ns \\
\hline State & 27 & 0.54 & & & & \\
\hline \multicolumn{7}{|l|}{ Compliance with person required to select winning tender } \\
\hline \multicolumn{7}{|l|}{ Federal } \\
\hline \multirow[t]{2}{*}{ State } & 17 & 0.95 & 1.207 & 42 & 0.234 & Ns \\
\hline & 27 & 0.83 & & & & \\
\hline Compliance with powers of the tenders' board & & & & & & \\
\hline Federal & 17 & 0.40 & 0.541 & 40 & 0.591 & Ns \\
\hline State & 27 & 0.32 & & & & \\
\hline Compliance bidding participation requirements & & & & & & \\
\hline Federal & 17 & 0.85 & 0.489 & 42 & 0.627 & Ns \\
\hline State & 27 & 0.79 & & & & \\
\hline
\end{tabular}

Compliance with form of dispute resolution 
Comparing Levels of Compliance with Public Procurement Act, 2007 in Project Delivery between Federal and State Tertiary Institutions in Southwest, Nigeria

Federal

State

Compliance with currency for stating values

Federal

State

Compliance with contents of the procurement

Federal

State

Compliance with approving authority

Federal

State

Compliance with procurement planning

Federal

State

Compliance with procurement plan

implementation

Federal

State

Compliance with committee on conduct of procurement

Federal

State

Compliance with procurement planning committee

members

Federal

State

Compliance with procurement processes

Federal

State

Compliance with mode of bidding /tendering

Federal

State

Compliance with bid opening procedures

Federal

State

Compliance with bid solicitation processes

Federal

State

Compliance with margins of mobilization

Federal

State

Compliance with basis for mobilization

Federal

State

Compliance with payment procedure

Federal

State

Compliance with procurement practices

Federal

State

Compliance with bidding methods

Federal

State

Compliance with procedure on restricted bidding

Federal

State

Compliance with value of consultancy services

Federal

State

Compliance with consultancy service procedure

$\begin{array}{llllll}17 & 0.45 & 2.107 & 42 & 0.041 & \mathrm{~S} \\ 27 & 0.16 & & & & \\ 17 & 0.95 & -1.098 & 42 & 0.278 & \mathrm{Ns} \\ 27 & 1.00 & & & & \\ & & & & & \\ 17 & 0.55 & 1.821 & 42 & 0.076 & \mathrm{Ns} \\ 27 & 0.43 & & & & \\ & & & & & \\ 17 & 0.60 & 0.381 & 42 & 0.705 & \mathrm{Ns} \\ 27 & 0.54 & & & & \\ & & & & & \\ 17 & 0.54 & 1.160 & 42 & 0.252 & \mathrm{Ns} \\ 27 & 0.45 & & & & \end{array}$

27

0.63

0.103

42

$0.918 \quad$ Ns

$17 \quad 0.7$

$27 \quad 0.65$

$\begin{array}{ll}17 & 0.53\end{array}$

$27 \quad 0.60$

$\begin{array}{llll}-0.760 & 42 & 0.451 & \text { Ns }\end{array}$

0.729

42

0.470

Ns

$\begin{array}{ll}17 & 0.47\end{array}$

42

0.546

Ns

$27 \quad 0.51$

$\begin{array}{ll}17 & 0.64\end{array}$

0.153

42

$0.879 \quad \mathrm{Ns}$

$27 \quad 0.63$

$17 \quad 0.35$

$27 \quad 0.41$

$-0.946$

42

$0.349 \quad \mathrm{Ns}$

$17 \quad 0.25$

$27 \quad 0.25$

17

0.65

0.63

17

0.33

0.000

42

1.000

Ns

$17 \quad 0.52$

0.279

42

$0.782 \quad \mathrm{Ns}$

$17 \quad 0.85$

$27 \quad 0.92$

$\begin{array}{ll}17 & 0.60\end{array}$

$27 \quad 0.58$

0.808

42

$0.423 \quad$ Ns

$$
-1.20
$$

42

$0.236 \quad \mathrm{Ns}$

$\begin{array}{ll}17 & 0.75\end{array}$

$27 \quad 0.71$

$\begin{array}{llll}-0.682 & 42 & 0.499 & \text { Ns }\end{array}$

$\begin{array}{llll}0.109 & 42 & 0.913 & \text { Ns }\end{array}$

$\begin{array}{llll}0.302 & 42 & 0.764 & \text { Ns }\end{array}$


Ebenezer Olutide Bamidele

Federal

State

Compliance with procedure for evaluating bids

Federal

State

Compliance with procedure for selecting bids

Federal

State

Overall compliance with Procurement Act

Federal

State

$\begin{array}{llllll}17 & 0.36 & -0.383 & 42 & 0.703 & \text { Ns } \\ 27 & 0.39 & & & & \\ 17 & 0.62 & 1.047 & 42 & 0.301 & \text { Ns } \\ 27 & 0.52 & & & & \\ 17 & 0.38 & -0.101 & 42 & 0.920 & \text { Ns } \\ 27 & 0.39 & & & & \\ 17 & 0.57 & 0.888 & 42 & 0.380 & \text { Ns } \\ 27 & 0.53 & & & & \end{array}$

$\mathrm{N}=$ No. of Respondents, $\mathrm{Df}=$ Degree of Freedom, Diff. $=$ Differences, $\mathrm{S}=$ Significant, Ns $=$ NonSignificant, BPP = Bureau of Public Procurement, $\mathrm{CNO}=$ Certificate of No Objection .

\section{DISCUSSION OF FINDINGS}

\subsection{Levels of Compliance with Public Procurement act, 2007 by Federal and State Public Tertiary Institutions in Southwest, Nigeria}

Result in Table 1 reveals that the mean compliance by both the Federal and State Tertiary Institutions with the provision of the Act on treatment of unclassified procurement records is (0.00). The implication of this result is that the two categories of PTIs did not comply with this provision of the Act at all. The requirement of the Act concerning this provision is that the institutions shall make available for public inspection all procurement records that were not classified as confidential. Non-compliance with this provision of the Act is suggestive of the institutions keeping information about their procurement records from scrutiny by the Public. This negates the principle of the Act on openness of procurement process and elimination of corruption in Public Procurement.

Table 1 also shows that both Federal and State Public Institutions recorded the same low level of compliance in two provisions of the Procurement Act namely: the time required for transmission of procurement proceedings and contract awarded every financial year to BPP (0.25) and permissible mobilization limit to contractor (0.25). Table 1 also reveals that Federal Tertiary Institutions recorded better compliance with the provisions of the Act than the States Tertiary Institutions in 17 provisions of the Act namely; funding of capital projects, period when certificate of no objection to is obtained from BPP, minimum number of bids to be received before contract award, criteria used to select contractors for capital projects, person responsible for final selection of winning tender, requirement for participating in bidding process, contents of procurement contracts, approving authority for conduct of procurement, process regarding the planning of procurement, process regarding implementation of procurement plans, organs/committee involved in the procurement of construction projects, processes adopted for the procurement of construction projects, activities performed during bid opening, basis for granting mobilization to contractor, procedure on restricted bidding, value of consultancy services for which open tendering is solicited and procedure for evaluating bids. On the other hand, the State Tertiary Institutions recorded higher compliance than the Federal PTIs in 10 provisions of the Act namely; basis for the award of contract for construction projects, procedure for procurement of capital project, procedure for payment of contractor/supplier that handled capital project, language of documentation of bids and contract agreement, award of contracts of capital projects, currency in which the values in procurement contract agreement are stated, members of procurement planning committee, mode of bidding/tendering for construction projects, procurement practices on construction projects and bidding methods for construction projects.

The results in Table 1 further reveals that both Federal and State Tertiary Institutions recorded very low compliance in nine provisions of the Act namely; value of projects for 
which certificate of No Objection is obtained, time allowed bidding before award, process applicable to bids excluded from evaluation, preparation and transmission time for records of proceedings and contract awarded each financial tear to BPP. Others include; treatment of unclassified procurement records, margins of mobilization to contractor, procedure for payment for procurement, procedure for procuring consultancy services and procedure for selecting bids. Table 1 also reveals that in the overall, the levels of compliance with the provisions of the procurement Act by Federal PTIs is higher (0.57) than that of the State PTIs (0.53).

The descriptive results of the level of compliance in Table 1 further shows that the Federal owned PTIs complied more than the State owned PTIs in the remaining provisions of the Act. The low level of compliance by the state PTIs could be as a result of the autonomy of the state government which allows them to dictate the rule to follow on procurement for which they are responsible for the funding. The result indicates that although both Federal and State PTIs are meant to comply with the provisions of the Procurement Act, state owned tertiary institutions exhibited lower level of compliance.

\subsection{Difference in the Levels of Compliance with Public Procurement Act 2007 between Federal and State PTIs}

Table 1 also shows that the p-value for the test of difference in the level of compliance with the procedure of primary form of dispute resolution in the procurement contract agreements between Federal and State Governments' Tertiary Institutions (0.041) is less than the critical p-value (0.05). Therefore, the test rejects the hypothesis that there is no significant difference in the level of compliance with PPA, 2007 based on ownership of PTIs. The implication of the result is that there is a significant difference in the level of compliance with the procedure of primary form of dispute resolution in the procurement contract agreements between Federal and State owned Tertiary Institutions. Hence ownership of the Tertiary Institutions has effect on the levels of compliance with this provision of the Act.

Table 1 further shows that the p-values for the test of difference in the levels of compliance with 38 provisions between Federal and State owned Tertiary Institutions are greater than the critical p-value (0.05), therefore, the test fails to reject the hypothesis which states that there is no significant difference in the level of compliance with PPA, 2007 between Federal and State owned Institutions. The results indicate that the level of compliance with 38 provisions of the PPA, 2007 is the same in Federal and State tertiary institutions. Hence, ownership of PTIs has no effect on the levels of compliance with the remaining 38 provisions of PPA, 2007. This finding tends to suggest that State Tertiary Institutions compare favourably with their Federal counterparts on compliance with the Procurement Act. The reason for compliance with the Act by State Procurement entities can be attributed to the activities of transparency and anti-corruption agencies namely: Economic and Financial Crime Commission (EFCC) and Independent Corrupt Practices Commission (ICPC) that cover all arms of government.

\section{CONCLUSIONS}

The study has compared the levels of compliance with Public Procurement Act 2007 between the State and Federal Tertiary Institutions in Southwest, Nigeria. Results from the study have established that the two categories of Institutions did not comply at all with one provision of the PPA, 2007 namely; the statement applicable to procurement record. The two categories of institutions recorded very low compliance in several provisions of the Act. The low compliance with the provisions of the Act by the two categories of the institutions would 
definitely affect the purpose for which the Act was enacted which centred at addressing corruption in Public Procurement and also to introduce international standard practices in Public Procurement in Nigeria. This low compliance could lead to various sharp practices in procurement process in the country which was prevalent before the enactment of the Act as well as the establishment of regulatory authority for monitoring procurement procedure in the public sector. However, the results reveal that Federal and State Tertiary Institutions recorded the same levels of compliance with two provisions of the Act whereas; Federal Tertiary Institutions recorded higher compliance than the state counterparts in majority of the provisions of the Act. The results also reveal that the two categories of institutions recorded very low compliance in 9 provisions of the Act. The results of the test of the research hypothesis reveal that the difference in the level of compliance by Federal and State PTIs differs significantly only in one provision namely; primary form of dispute resolution in procurement contract agreement

The study therefore concludes that the compliance with the provisions of the Public Procurement Act by State and Federal Tertiary Institutions is the same except on one provision that relates to primary form of dispute resolution in the procurement contract agreements. The scenario is an indication that Federal tertiary institutions that are Federal Government Agencies who are expected to comply fully with the Act places the same importance on compliance with the Act with their State Government owned counterparts. Based on the conclusion, the study recommends stricter enforcement on compliance with the provisions of the Act by the Bureau of Public Procurement to ensure full compliance and achievement of the objectives of the Act. It also recommends that more training should be given to the two categories of PTIs on the provisions where they have very low compliance so that they will know how to have better compliance as well as the benefit of complying so that the objective of the Act could be realised. State PTIs should also be trained specifically to have improved compliance with the Act since they were already complying with the provisions of the Act despite the fact that the Act was made essentially for those Institutions sponsored by the Federal Government.

\section{SUGGESTION FOR FURTHER STUDIES}

Public Procurement Act is applicable to all the Public entities in the entire six political zones in Nigeria. This study covers only Public Tertiary Institutions in one of the six zones (Southwest zone) of the country. It is therefore suggested that the level of compliance with the Act in Public Tertiary Institutions as well as other Public entities in other five zones of the country be investigated. Similarly, it is discovered in the study that the level of compliance with several provisions of the Act is low. Since the causes of non- compliance with the Act is not within the scope of this study, it is therefore recommended for further study.

\section{REFERENCES}

[1] Ayangade, J., Wahab, A. and Alake, O. (2009). An Investigation of the Performance of Due Process Mechanism in the Execution of Construction Projects in Nigeria, Civil Engineering Dimension, 62(11), 1-7.

[2] Bureau of Public Procurement BPP, (2011). Procurement Procedures Manual for Public Procurement in Nigeria. Abuja, Nigeria: Bureau of Public Procurement State House

[3] Claren, N. (2017). You are What You Buy. The First International Standard for Sustainable Procurement. Available: http ://www.iso.org/daily/170421 (Accessed:2020, February 29).

[4] Federal Republic of Nigeria Official Gazette, FGN (2007). Public Procurement Act 2007. Lagos, Nigeria: Federal Government Printer, Lagos, Nigeria. 
Comparing Levels of Compliance with Public Procurement Act, 2007 in Project Delivery between Federal and State Tertiary Institutions in Southwest, Nigeria

[5] Hunja, R. R. (2003). "Obstacles to public procurement reform in developing countries", In Arrowsmith, S. and Trybus, M (Eds.) Public Procurement: The continuing Revolution. Kluwer International, 13-22.

[6] Innocent, N., Okeke G. and Sabina, E. (2015). 'Due Process and Procurement Procedure in the Nigerian Public Service (Content Analysis Perspective)', International Journal of Innovative Research in Management, 5, 38-44

[7] Mukura, P., Shalle, N., Kanda, M. and Ngatia, P. (2016). Role of public procurement authority on procurement regulations in Kenyan state corporations: A case study of kenyan electricity generating company (KenGen). International Journal of Academic Research in Accounting, Financial and Management Science, 6(3), 190-201.

[8] Musa, S. J., Success, B. E. and Nwaorgu, I. A. (2014). 'The Public Procurement Reform in Nigeria: Implimentation and Compliance Challenges', Journal of Asian Business Strategy, 4(11), 149-162

[9] Public and Private Development Centre, PPDC. (2012). Walking the Path of Procurement Reforms in Nigeria. Compliance with Public Procurement Act, 2007. An Evaluation of Procuring Entities, Civil Society Organizations, Bidders and the Bureau of Public Procurement. Public and Private Development Centre Ltd by Guarantee (PPDC). Abuja, Nigeria.

[10] Public Procurement and Disposal of Public Assets Authority, PPDA. (2006). Procurement and Disposal Compliance Check Report of National Social Security Fund. Kampala, Uganda: Uganda Government Printing Office.

[11] Transparency International (2006). Handbook on Curbing Corruption on Public Procurement www.transparency.org.

[12] Wahab, K. (2014). Construction and Housing in Nigeria: Construction Economy and Management. University Press PLC: Nigeria.

[13] Sope, W. (2014). A comparative analysis of the Nigerian public procurement against international best practice. Journal of African Law, 59(1), 85-98. 